\title{
Sickness absence and duration of service in the Post Office 1982-3
}

\author{
S J SEARLE \\ From the Midlands Postal Board, Birmingham B3 $1 \mathrm{HQ}$
}

ABSTRACT For some years a high severity of sickness absence has been noted in young postmen. This cross sectional study is of 4419 male postmen and 787 male postal officers and postal assistants, of whom 3753 and 709 respectively were employed for the whole year of the study from 1 April 1982 to 31 March 1983. A stratification technique was used to assess the influence of duration of service on sickness absence within certain age ranges. Differences in the proportion of men taking more than a stated number of spells or days, in groups of short and long service, are tested statistically using Chi square tests with a continuity correction. Statistically significant reductions, with increasing duration of service, are found for self certificated spells and days in all postmen and for certificated spells but not days in younger postmen. Older postal officers and postal assistants have a statistically significant reduction in self certificated spells. Young postal officers and postal assistants show no significant change in spells and days of sickness absence with duration of service. It is concluded that the excess severity of sickness absence in younger postmen is due to self certificated absence rather than certificated absence. The difference in severity of sickness absence in various diagnostic groups with increasing duration of service is discussed. The limitations of a cross sectional study mean that further work is required to investigate this problem using longitudinal techniques.

For some years a higher than expected severity of sickness absence has been noted in young men employed in the Post Office. ${ }^{12}$ Studies in the London postal region showed that this problem was confined to employees in the postman grade and that new entrants of all ages in the postman grade also had a higher severity of sickness absence that expected. ${ }^{3}$

\section{Aims of the present study}

The effect of duration of service on absence attributable to sickness in men in the postman grade and clerical grades is examined to see whether the high rate of absence in young men in the Post Office is unique to the postman grade and to assess the relative contribution of age and duration of service to this problem. The population studied is the national Post Office population in England, Wales, Scotland, and Northern Ireland. Taylor showed a close association between certificated sickness absence and medical wastage in the Post Office, suggesting that groups

Accepted 5 December 1985 with high rates of absence are in fact less healthy than those with lower rates because almost all medical wastage is due to death or long standing objective disease. ${ }^{4}$ As young men in the Post Office are a group with relatively high rates of certificated sickness absence this study looks at the distribution of absence by broad diagnostic groups in order to consider possible preventive health measures.

\section{Personal factors and sickness absence}

The many factors known to influence sickness absence are listed elsewhere, ${ }^{5}$ the three most important being job, sex, and age. Job grade has a pronounced effect on sickness absence with jobs of greater responsibility and less physical demand, such as managerial and clerical jobs, having lower rates than more physically demanding lower grade jobs, such as unskilled jobs. Having taken age and sex into account it is still possible for job grade in an organisation to account for threefold differences in sick rates. ${ }^{6}$ A distinction between the effects of duration of service and of age is not clear. Some 458 
workers describe a trend for male workers of "fewer but longer" absences with increasing age ${ }^{6-8}$ but an increase in the duration and frequency of absence with age has also been reported. ${ }^{9}$ Regarding duration of service low sick rates have been reported where there is lack of provision of company sick pay during the early months of service ${ }^{10}$ but otherwise frequency of absence has been found to decrease with increased duration of service. ${ }^{911}$

In summary previous work on age and sickness absence suggests an increasing severity of absence with increasing age and a decreasing frequency of absence with increasing age. This is in contrast to the combination of high frequency and high severity of absence seen in young men in the Post Office.

\section{SELF CERTIFICATION}

Self certification for the first seven days in any spell of sickness absence was introduced by the Department of Health and Social Security in June 1982. Before this the Post Office operated a system of uncertificated leave privilege whereby employees were allowed to take up to ten days a year as uncertificated sickness absence with a maximum of five working days in one spell.

The period under study runs from 1 April 1982 to 31 March 1983 and the absences recorded as self certificated include those in the first two months of the year when such absences were under the previous non-certificated system. There is no evidence of any substantial increase in uncertificated absence in the Post Office ${ }^{2}$ since the introduction of self certification.

\section{DUTIES OF POSTMEN, POSTAL OFFICERS, AND} POSTAL ASSISTANTS

Postmen are responsible for the collection, sorting, and delivery of letter and parcel mail, often walking several miles a day on all types of terrain and in all weathers carrying a pouch weighing up to $15 \mathrm{~kg}$. Repeated lifting of bags of mail weighing up to $22.5 \mathrm{~kg}$ is also required. Riding a pedal cycle and driving motor vehicles of all sizes ranging from small vans up to heavy goods vehicles may be required. Shiftwork is also necessary with early hours of attendance on the first shift of the day starting at 0500 or 0600 . The allocation of postmen's duties depends on duration of service with longer service postmen getting the more sought after jobs. For example, new recruits will tend to be on reserve duties with frequent changes of delivery round, progressing later to a regular delivery round. After several years of service a postman is more likely to have the choice of a vehicle delivery round in a pleasant area. In large offices postmen with longer service also have a greater choice between outdoor work and duties within the office.

The clerical grades comprise postal officers and postal assistants. Postal officers initially undertake duties at the public Post Office counter dealing with all necessary transactions. Later they may transfer to purely clerical work away from the counter, which is not necessarily sedentary and can entail standing and repeated heavy lifting. Postal assistants undertake clerical duties at a lower level than postal officers. In general there is little shift work undertaken by these grades although some evening work is occasionally undertaken such as inquiry work dealing with television licences.

\section{Method}

\section{STUDY DESIGN}

The study design is a cross sectional study of absence attributable to sickness in Post Office employees from 1 April 1982 to 31 March 1983. The database for the study is the sickness absence return sample (SARS) of the Post Office for 1982-3. The SARS is described elsewhere. ${ }^{12}$ A stratified sample taken from 146997 Post Office employees, it contains information regarding the number of days and number of spells of absence attibutable to sickness, both certificated and self certificated, for each employee in the sample between 1 April 1982 and 31 March 1983. For each employee sampled information is available on sex, date of birth, date of entry into the Post Office, work grade, and place of work as well as data on sickness absence coded by diagnosis as stated on the medical certificate or self certificate. The effect of duration of service on sickness in male postmen and male clerical staff is investigated in all age groups to determine whether or not long service employees exhibit different absence behaviour than their peers with relatively shorter service.

\section{MEASURES OF ABSENCE ATTRIBUTED TO SICKNESS}

The measures of sickness absence used are frequency (the number of spells of sickness absence starting between 1 April 1982 and 31 March 1983 for each employee) and severity (the total number of calendar days of sickness absence taken by each employee between 1 April 1982 and 31 March 1983). The frequency and severity of medically certificated absence and of self certificated absence is considered separately. Medically certificated absence is most likely to reflect "unavoidable" absence due to medical conditions and self certificated absence is most likely to reflect "avoidable" or attitudinal absence not necessarily related to the presence of a medical condition. These distinctions are not hard and fast since some single day absences may be due to serious medical conditions and some certified spells lasting a week or more may not. 
STUDY POPULATION

The study population comprises $\mathbf{4 4 1 9}$ male postmen and 787 male clerical staff (postal officers and postal assistants) of whom 3753 and 709 respectively were employed for the whole year.

\section{EFFECT OF DURATION OF SER VICE}

To study the effect of duration of service on measures of sickness absence a stratification technique is used. The rates for frequency and severity of sickness absence, total, certificated, and non-certificated are cross tabulated by age and duration of service. Age is taken as age at 31 December 1982. Duration of service is calculated to 31 March 1983. For employees leaving during the year the duration of service is taken as that to the date of leaving. Tables 1 and 2 show the man-years contributing to the rates in each age and duration of service class. By using frequency distributions it is possible to test differences in the proportion of individuals exceeding certain limits of spells and days, using contingency tables and Chi squared tests. This technique is used to test the following hypotheses:

(1) That the frequency of sickness absence decreases with increasing duration of service.

(2) That the severity of sickness absence decreases with increasing duration of service.

As age may result in an increased severity of sickness absence, increasing age could tend to mask the possible negative effect of increasing duration of service. For this reason the frequency distributions are constructed separately for employees aged under $\mathbf{4 0}$ and employees aged 40 and over, comparing those with short service (less than 10 years) with those with long service (10 years or more) in younger and older employees respectively.

\section{SICKNESS ABSENCE BY DIAGNOSIS}

Rates of sickness absence by broad diagnostic groups, based on the main chapters of the International Classification of Diseases, are computed for male postmen and male postal officers and postal assistants together. This allows some impression to be gained of diagnostic groups which contribute to any differences detected between the duration of service classes in each age group, suggesting possible preventive measures to be taken by the occupational health service.

\section{Results}

For convenience the under $40 \mathrm{~s}$ and over $40 \mathrm{~s}$ in each grade group will be considered separately. A summary of the significant results is shown at table 3 .

POSTMEN AGED UNDER 40

The frequency of absence in postmen under 40 fell with increasing duration of service, both for self certificated and certificated spells (table $7 *$ ). For both types of absence there were low rates for those with under one year of service. There was a statistically significant fall in the proportion of men with longer service taking four spells or more of self certificated absence $(p<0.025)$ and two spells or more of certificated absence $(p<0.01)$.

The severity of self certificated absence in postmen under $\mathbf{4 0}$ fell with increasing duration of service after the first two years of service (table 8). There was a statistically significant fall $(\mathrm{p}<0.025)$ in the proportion of men with longer service taking seven days or more of self certificated absence.

The severity of absence fell with increasing duration of service in all disease groups except for diseases of the arteries and veins (fourfold increase in days and threefold increase in spells), digestive system disorders ( $21 \%$ increase in days), and "other" conditions (33\% increase in days). The disease groups with the largest falls with increasing duration of service, were, in decreasing order of magnitude, psychiatric conditions, ischaemic heart disease, nervous system disorders, musculoskeletal disorders, respiratory disorders, and "other" injuries and accidents (table 4).

\section{POSTMEN AGED 40 AND OVER}

The frequency of self certificated absence in postmen aged 40 and over fell with increasing duration of service. There was a statistically significant fall ( $p<$ 0.001 ) in the proportion of men with longer service taking four spells or more of self certificated absence.

The severity of self certificated absence in postmen aged 40 and over fell with increasing duration of service. There was a statistically significant fall $(p<$ 0.01 ) in the proportion of men with longer service taking eight days or more of self certificated absence.

Table 5 shows the sickness absence by disease group for postmen aged $\mathbf{4 0}$ and over. There was a rise in severity of absence with increasing duration of service in most disease groups. The conditions showing the largest rises with longer service were ischaemic heart disease and "other" injuries and accidents. Those disease groups showing a fall in severity with longer service were heart and circulatory disorders, musculoskeletal disorders, accidents off duty, disorders of the nervous system, and influenza.

\section{POSTAL OFFICERS AND POSTAL ASSISTANTS} UNDER 40

No statistically significant changes in either frequency or severity of absence with increasing duration of service in this group were shown. The mean spells and

*Tables 7-10 inclusive showing cross tabulation of age and duration of service, for mean spells and days of absence, in postmen and postal officers may be obtained from the author. 
Sickness absence and duration of service in the Post Office 1982-3

Table 1 Male postmen: total man years in sample

\begin{tabular}{|c|c|c|c|c|c|c|c|}
\hline \multirow{2}{*}{$\begin{array}{l}\text { Duration of service } \\
\text { (years) }\end{array}$} & \multicolumn{7}{|c|}{ Age range (years) } \\
\hline & $<20$ & $20-29$ & $30-39$ & $40-49$ & $50-59$ & $>60$ & Total \\
\hline $\begin{array}{l}<1 \\
1 \\
2 \\
3-5 \\
6-10 \\
11-15 \\
16-20 \\
21-30 \\
31-40 \\
\geqslant 40\end{array}$ & $\begin{array}{r}88 \\
138 \\
133 \\
51\end{array}$ & $\begin{array}{r}52 \\
71 \\
119 \\
366 \\
166 \\
34\end{array}$ & $\begin{array}{r}22 \\
31 \\
56 \\
202 \\
236 \\
130 \\
58 \\
19\end{array}$ & $\begin{array}{r}16 \\
30 \\
39 \\
134 \\
154 \\
138 \\
160 \\
117 \\
40\end{array}$ & $\begin{array}{r}56 \\
13 \\
21 \\
73 \\
172 \\
151 \\
151 \\
197 \\
85 \\
3\end{array}$ & $\begin{array}{r}4 \\
10 \\
41 \\
55 \\
51 \\
87 \\
53 \\
7\end{array}$ & $\begin{array}{r}234 \\
283 \\
372 \\
836 \\
769 \\
508 \\
420 \\
420 \\
178 \\
10\end{array}$ \\
\hline Total & 410 & 808 & 754 & 828 & 922 & 308 & 4030 \\
\hline
\end{tabular}

Table 2 Male postal officers and postal assistants: total man years in sample

\begin{tabular}{|c|c|c|c|c|c|c|c|}
\hline \multirow{2}{*}{$\begin{array}{l}\text { Duration of service } \\
\text { (years) }\end{array}$} & \multicolumn{7}{|c|}{ Age range (years) } \\
\hline & $<20$ & $20-29$ & $30-39$ & $40-49$ & $50-59$ & $>60$ & Total \\
\hline $\begin{array}{l}<1 \\
1 \\
2 \\
3-5 \\
6-10 \\
11-15 \\
16-20 \\
21-30 \\
31-40 \\
\geqslant 40\end{array}$ & $\begin{array}{r}6 \\
8 \\
10 \\
4 \\
- \\
- \\
- \\
- \\
-\end{array}$ & $\begin{array}{r}11 \\
20 \\
32 \\
102 \\
49 \\
9 \\
- \\
- \\
-\end{array}$ & $\begin{array}{r}2 \\
9 \\
5 \\
27 \\
41 \\
42 \\
17 \\
6 \\
-\end{array}$ & $\begin{array}{r}3 \\
- \\
4 \\
11 \\
12 \\
29 \\
25 \\
32 \\
7 \\
-\end{array}$ & $\begin{array}{r}- \\
1 \\
1 \\
2 \\
13 \\
19 \\
11 \\
57 \\
45 \\
14\end{array}$ & $\begin{array}{r}- \\
1 \\
-4 \\
5 \\
8 \\
12 \\
23 \\
11\end{array}$ & $\begin{array}{r}22 \\
38 \\
53 \\
146 \\
119 \\
104 \\
61 \\
107 \\
75 \\
25\end{array}$ \\
\hline Total & 28 & 223 & 149 & 123 & 163 & 64 & 750 \\
\hline
\end{tabular}

Table 3 Comparison of proportions taking "high" absence between those with short service (10 years and less) and long service (more than 10 years)

\begin{tabular}{|c|c|c|c|c|c|c|c|c|}
\hline Occupational group & $\begin{array}{l}\text { Age group } \\
\text { (years) }\end{array}$ & $\begin{array}{l}\text { Definition of "high" } \\
\text { absence }\end{array}$ & $\begin{array}{l}\text { Duration of } \\
\text { service }\end{array}$ & No in sample & $\begin{array}{l}\text { No with "high" } \\
\text { absence }\end{array}$ & $\begin{array}{l}\text { Percentage with } \\
\text { "high" absence }\end{array}$ & $\begin{array}{l}\text { Corrected } \chi^{2} \\
\text { statistic }\end{array}$ & Probability \\
\hline $\begin{array}{l}\text { ostal officers and } \\
\text { oostal assistants }\end{array}$ & $\geqslant 40$ & $\begin{array}{l}4 \text { Self certificated } \\
\text { spells or more } \\
2 \text { certificated spells } \\
\text { or more } \\
7 \text { Self certificated days } \\
\text { or more } \\
4 \text { Self certificated } \\
\text { spells or more } \\
8 \text { Self certificated days } \\
\text { or more } \\
3 \text { Self certificated } \\
\text { spells or more }\end{array}$ & $\begin{array}{l}\text { Short } \\
\text { Long } \\
\text { Short } \\
\text { Long } \\
\text { Short } \\
\text { Long } \\
\text { Short } \\
\text { Long } \\
\text { Short } \\
\text { Long } \\
\text { Short } \\
\text { Long }\end{array}$ & $\begin{array}{r}1601 \\
239 \\
1601 \\
239 \\
1601 \\
239 \\
674 \\
1239 \\
674 \\
1239 \\
48 \\
284\end{array}$ & $\begin{array}{r}472 \\
53 \\
211 \\
15 \\
455 \\
50 \\
90 \\
102 \\
82 \\
98 \\
9 \\
23\end{array}$ & $\begin{array}{r}29 \\
22 \\
13 \\
6 \\
28 \\
21 \\
13 \\
8 \\
12 \\
8 \\
19 \\
8\end{array}$ & $\begin{array}{r}5 \cdot 09 \\
8 \cdot 61 \\
5 \cdot 48 \\
12 \cdot 17 \\
8 \cdot 80 \\
4 \cdot 18\end{array}$ & $\begin{array}{l}0.025 \\
0.01 \\
0.025 \\
0.001 \\
0.01 \\
0.05\end{array}$ \\
\hline
\end{tabular}

days of absence per man a year were less than half those seen for postmen under 40 (tables 7-10).

\section{POSTAL OFFICERS AND POSTAL ASSISTANTS}

AGED 40 AND OVER

The frequency of self certificated absence in postal officers and postal assistants aged 40 and over fell with increasing duration of service. There was a statistically significant fall $(p<0.05)$ in the proportion of men with longer service taking three spells or more of self certificated absence. This may have been due to an age effect (spells generally decrease with age) as the longer service group had a significantly higher proportion of men aged 50 and over than the short service group $(p<0.001)$. There were no pronounced differences, however, in rates of self certificated spells with increasing age in this particular group (table 8).

Sickness absence by disease group for postal 
Table 4 Postmen under 40: sickness absence by disease group

\begin{tabular}{|c|c|c|c|c|}
\hline & \multicolumn{2}{|l|}{ Mean No of spells } & \multicolumn{2}{|l|}{ Mean No of days } \\
\hline & 10 years service or less & Over 10 years service & 10 years service or less & Over 10 years service \\
\hline All disease groups & $3 \cdot 212$ & $2 \cdot 461$ & $14 \cdot 382$ & $12 \cdot 423$ \\
\hline $\begin{array}{l}\text { Disease groups: } \\
\text { Influenza } \\
\text { Bronchitis } \\
\text { Other respiratory diseases } \\
\text { All respiratory diseases } \\
\text { Psychiatric } \\
\text { Nervous system } \\
\text { Cancers } \\
\text { Ischaemic heart disease } \\
\text { Other heart/circulatory disease } \\
\text { Diseases of arteries or veins } \\
\text { Digestive system } \\
\text { Musculoskeletal } \\
\text { Accidents on duty } \\
\text { Accidents off duty } \\
\text { Other injuries/accidents } \\
\text { Total injuries/accidents } \\
\text { Other conditions }\end{array}$ & $\begin{array}{l}0.382 \\
0.033 \\
0.462 \\
0.877 \\
0.039 \\
0.142 \\
0.001 \\
0.026 \\
0.001 \\
0.009 \\
0.812 \\
0.200 \\
0.072 \\
0.147 \\
0.188 \\
0.406 \\
0.698\end{array}$ & $\begin{array}{l}0.311 \\
0.029 \\
0.353 \\
0.693 \\
0.021 \\
0.112 \\
0.000 \\
0.012 \\
0.000 \\
0.037 \\
0.594 \\
0.166 \\
0.042 \\
0.095 \\
0.125 \\
0.262 \\
0.565\end{array}$ & $\begin{array}{l}1.353 \\
0.244 \\
1.583 \\
3.160 \\
0.722 \\
0.370 \\
0.002 \\
0.072 \\
0.001 \\
0.066 \\
1.787 \\
1.789 \\
0.555 \\
1.819 \\
1.464 \\
3.839 \\
2.575\end{array}$ & $\begin{array}{l}1.046 \\
0.199 \\
0.909 \\
2.154 \\
0.120 \\
0.228 \\
0.000 \\
0.021 \\
0.000 \\
0.328 \\
2.171 \\
0.959 \\
0.490 \\
1.673 \\
0.876 \\
3.038 \\
3.404\end{array}$ \\
\hline
\end{tabular}

Table 5 Postmen 40 and over: sickness absence by disease group

\begin{tabular}{|c|c|c|c|c|}
\hline & \multicolumn{2}{|l|}{ Mean No of spells } & \multicolumn{2}{|l|}{ Mean No of days } \\
\hline & 10 years service or less & Over 10 years service & 10 years service or less & Over 10 years service \\
\hline All disease groups & 1.956 & $1 \cdot 712$ & 12.047 & $13 \cdot 488$ \\
\hline $\begin{array}{l}\text { Disease groups: } \\
\text { Influenza } \\
\text { Bronchitis } \\
\text { Other respiratory diseases } \\
\text { All respiratory diseases } \\
\text { Psychiatric } \\
\text { Nervous system } \\
\text { Cancers } \\
\text { Ischaemic heart disease } \\
\text { Other heart/circulatory disease } \\
\text { Diseases of arteries or veins } \\
\text { Digestive system } \\
\text { Musculoskeletal } \\
\text { Accidents on duty } \\
\text { Accidents off duty } \\
\text { Other injuries/accidents } \\
\text { Total injuries/accidents } \\
\text { Other conditions }\end{array}$ & $\begin{array}{l}0.273 \\
0.042 \\
0.231 \\
0.547 \\
0.017 \\
0.095 \\
0.000 \\
0.020 \\
0.007 \\
0.008 \\
0.456 \\
0.170 \\
0.067 \\
0.042 \\
0.090 \\
0.199 \\
0.437\end{array}$ & $\begin{array}{l}0.206 \\
0.039 \\
0.239 \\
0.484 \\
0.021 \\
0.075 \\
0.000 \\
0.030 \\
0.012 \\
0.016 \\
0.345 \\
0.206 \\
0.040 \\
0.037 \\
0.090 \\
0.168 \\
0.355\end{array}$ & $\begin{array}{l}1.119 \\
0.600 \\
0.922 \\
2.641 \\
0.220 \\
0.521 \\
0.000 \\
0.230 \\
0.428 \\
0.062 \\
1.989 \\
2.413 \\
0.596 \\
0.646 \\
0.528 \\
1.770 \\
1.773\end{array}$ & $\begin{array}{l}0.899 \\
0.942 \\
1.130 \\
2.970 \\
0.233 \\
0.385 \\
0.000 \\
1.336 \\
0.188 \\
0.096 \\
1.539 \\
1.595 \\
0.735 \\
0.429 \\
1.116 \\
2.280 \\
2.866\end{array}$ \\
\hline
\end{tabular}

Table 6 Postal officers and postal assistants 40 and over: sickness absence by disease group

\begin{tabular}{|c|c|c|c|c|}
\hline & \multicolumn{2}{|l|}{ Mean No of spells } & \multicolumn{2}{|l|}{ Mean No of days } \\
\hline & 10 years service or less & Over 10 years service & 10 years service or less & Over 10 years service \\
\hline All disease groups & 1.601 & $1 \cdot 182$ & $17 \cdot 805$ & $14 \cdot 676$ \\
\hline $\begin{array}{l}\text { Disease groups: } \\
\text { Influenza } \\
\text { Bronchitis } \\
\text { Other respiratory diseases } \\
\text { All respiratory diseases } \\
\text { Psychiatric } \\
\text { Nervous system } \\
\text { Cancers } \\
\text { Ischaemic heart disease } \\
\text { Other heart/circulatory disease } \\
\text { Diseases of arteries or veins } \\
\text { Digestive system } \\
\text { Musculoskeletal } \\
\text { Accidents on duty } \\
\text { Accidents off duty } \\
\text { Other injuries/accidents } \\
\text { Total injuries/accidents } \\
\text { Other conditions }\end{array}$ & $\begin{array}{l}0.154 \\
0.019 \\
0.444 \\
0.617 \\
0.019 \\
0.019 \\
0.000 \\
0.039 \\
0.019 \\
0.039 \\
0.231 \\
0.096 \cdots \\
0.000 \\
0.039 \\
0.058 \\
0.096 \\
0.424\end{array}$ & $\begin{array}{l}0.128 \\
0.040 \\
0.215 \\
0.383 \\
0.017 \\
0.054 \\
0.000 \\
0.027 \\
0.020 \\
0.003 \\
0.205 \\
0.144 \\
0.000 \\
0.024 \\
0.047 \\
0.071 \\
0.259\end{array}$ & $\begin{array}{l}0.444 \\
0.039 \\
2.334 \\
2.816 \\
1.196 \\
0.212 \\
0.000 \\
2.739 \\
0.077 \\
0.868 \\
1.292 \\
7.041 \\
0.000 \\
0.096 \\
0.212 \\
0.309 \\
1.254\end{array}$ & $\begin{array}{l}0.551 \\
0.326 \\
0.688 \\
1.565 \\
1.713 \\
1.337 \\
0.000 \\
1.944 \\
1.071 \\
0.201 \\
0.652 \\
3.200 \\
0.000 \\
0.413 \\
0.591 \\
1.004 \\
1.988\end{array}$ \\
\hline
\end{tabular}


officers and postal assistants aged 40 and over is shown in table 6 . The largest rises in severity with long service were (in order of decreasing severity) heart and circulatory disorders, bronchitis, and nervous system disorders. Falls in severity with increasing duration of service were seen for diseases of arteries and veins, "other" respiratory disorders, musculoskeletal disorders, digestive system disorders, all respiratory disorders, and ischaemic heart disease.

\section{Discussion}

This section considers the four groups defined by occupation and age in order by discussing their main differences. In common with all cross sectional studies this can only provide answers to some of the questions, others requiring investigation by longitudinal studies.

\section{Postmen under 40}

In postmen under $\mathbf{4 0}$ there were falls in spells of sickness absence, both certificated and self certificated and in days of self certificated absence with longer service. Most self certificated spells were of short duration, $53 \%$ lasting for two days or under, therefore both days and spells of self certificated absence would be expected to show a similar pattern. A lower proportion of postmen with long service than with short service took seven days or more self certificated absence. Self certificated absence may now be taken for up to seven days in any one spell and such absence probably accounts mainly for the increased severity of sickness absence found in young postmen.

Some self certificated absences have a medical basis and some certificated absences do not. It is therefore worth considering some of the causes, by diagnosis, which improved with long service in younger postmen. The greatest reductions were for psychiatric conditions, cardiac disease, diseases of the nervous system, musculoskeletal conditions, accidents and injuries, and respiratory conditions (except influenza and bronchitis). This reduction with long service could be due to reduced prevalence with increasing duration of service or due to medical wastage of employees with certain conditions. This cross sectional study does not allow conclusions to be drawn regarding either of these possibilities; a longitudinal study would be necessary to assess these factors.

In the early years of service, as previously described, there is less stability of duties and hours of attendance in postmen's work. This improves with increasing service as an individual will be more able to pick a congenial duty. This could account for the relatively higher rates of absence due to psychiatric conditions in those with short service. The reduction in rates for cardiac disease or disorders of the nervous system is more likely to reflect the problem of long term provision of modified duties (involving less heavy lifting, bending, and stooping) for those with short service or their early retirement on medical grounds. The reduction in rates for musculoskeletal disorders, accidents, and injuries with longer service may be due to increasing familiarity with manual handling methods and equipment. The importance of adequate training in manual handling methods at induction and on change of job or workplace involving the use of unfamiliar equipment is clear. The decrease in rates for respiratory disorders might relate to increased immunity with increasing age or perhaps to longer service employees being in a more congenial job.

The occupational health service should provide counselling to individuals with health problems and health education to individuals and groups. Jenkins reports an association between the minor psychiatric morbidity and increases in certificated sickness absence and also such morbidity as is under-reported on medical certificates. ${ }^{13}$ In view of this and the apparent reduction in psychiatric conditions with longer service a longitudinal study to investigate minor psychiatric morbidity in postmen would be useful.

\section{POSTMEN AGED 40 YEARS AND OVER}

In older postmen there were falls in both spells and days of self certificated absence with longer service but certificated absence was found to rise in severity with age.

Most disease groups showed a rise in severity of absence with longer service, probably associated with increasing age.

The analysis of sickness absence by diagnostic group showed a rise in severity in most groups, particularly for ischaemic heart disease and for accidents and injuries (apart from those sustained off duty). This pattern probably reflects the increasing age of this group and slower recovery rates for medical conditions such as myocardial infarction and fractures. A reduction in absence in the longer service group for accidents off duty probably reflects a lower participation in contact sports than the younger age group. The reduction in the other groups may reflect greater possibilities for return to work on modified duties for men with longer service.

\section{POSTAL OFFICERS AND POSTAL ASSISTANTS UNDER 40}

There is no apparent influence of duration of service in this group. The low rates for spells and days of absence compared with postmen reflects the 
difference in duties, this group being employed mainly on sedentary clerical duties.

POSTAL OFFICERS AND POSTAL ASSISTANTS

AGED 40 YEARS AND OVER

The frequency of self certificated spells of absence fell in the longer service group. This was unlikely to have been purely due to age. The postal officers all start work initially on the public Post Office counter and remain there for several years until they have an option to go on a clerical duty away from the counter. After 10 years service or more most will be in the type of work that suits them best. This could explain the fall in self certificated days with increasing duration of service. Most diagnostic groups showed an increase in severity with longer service, in particular heart and circulatory disease, bronchitis, and diseases of the nervous system. This may reflect the fact that, because these conditions do not necessarily handicap the employee from the point of view of undertaking clerical work, postal officers are less likely than postmen to be retired on medical grounds for such conditions.

\section{Summary of conclusions}

The frequency of both self certificated and certificated absence fell with increasing duration of service in younger postmen as did the frequency of self certificated absence in older postmen. The severity of self certificated absence fell with increasing duration of service in all postmen. In postal officers and postal assistants there was a reduced frequency of self certificated absence in older postal officers but no effect on severity of absence with increasing duration of service. Younger postal officers and postal assistants had low rates of absence, hence no significant changes with increasing duration of service. It is concluded that the excessive sickness absence seen in young postmen is mainly due to self certificated absence. The differences in sickness absence by diagnostic group, with long and short service, may be related to different possibilities for providing modified duties on a long term basis for employees of different grades and differing duration of service. Finally, the fact that the less congenial duties of post- men have to be done by those with the least service may also influence the levels of self certificated absence.

This study is based on material included in a report for the MSc (occupational medicine) degree at London University. I thank Dr Stuart Pocock for initial discussion on statistical methods and Dr Peter Taylor for helpful advice as supervisor during the study and in the preparation of the paper. I also acknowledge the help and encouragement of Dr Michael McDonald, chief medical officer of the Post Office, and Mr Roger Langford of the economics and statistics division of the Post Office for help in data processing.

\section{References}

${ }^{1}$ Post Office. Annual report on sickness absence, and medical wastage 1979-80. Post Office and National Girobank. London: Post Office, 1980.

${ }^{2}$ Post Office. Annual report on sickness absence, and medical wastage 1982-3. Post Office and National Girobank. London: Post Office, 1983.

${ }^{3}$ Post Office. Annual report on the Post Office occupational health service by the chief medical officer 1983-4. London: Post Office, 1984:8-11, xvii-xxvii.

${ }^{4}$ Taylor PJ. Occupational and regional associations of death, disablement, and sickness absence among Post Office staff 1972-5. Br J Ind Med 1976;33:230-5.

${ }^{5}$ Taylor PJ. Causes and control of absenteeism. Encyclopaedia of occupational health and safety. Geneva: International Labour Office, 1983:4-8.

${ }^{6}$ Taylor PJ. Definitions and statistics of absenteeism. Encyclopaedia of occupational health and safety. Geneva: International Labour Office, 1983:8-10.

${ }^{7}$ Nicholson N, Brown CA, Chadwick-Jones JK. Absence from work and personal characteristics. J Appl Psychol 1961;35:31-5.

${ }^{8}$ Behrend $\mathrm{H}$, Pocock S. Absence and the individual: a six year study in one organisation. International Labour Review 1976;14: 311-27.

${ }^{9}$ Cooper R, Payne RL. Age and absence: a longitudinal study in three firms. Occupational Psychology 1961;35:31-5.

${ }^{10}$ Pocock SJ. Relationship between sickness absence and length of service. Br J Ind Med 1973;30:63-70.

${ }^{11}$ Popp PO, Belohlav JA. Absenteeism in a low status work environment. Academy of Management Journal 1982;25, part 3:677-83.

12 Searle SJ. Sickness, absence and length of service in the Post Office 1982-3. London: University of London, 1985. (MSc report.).

13 Jenkins R. Minor psychiatric morbidity in employed young men and women and its contribution to sickness absence. $\mathrm{Br} J$ Ind Med 1985;42:147-54. 